MAKING THE PAPER

\section{David Leigh}

Nature Vol.445(xi)/1 February 2007

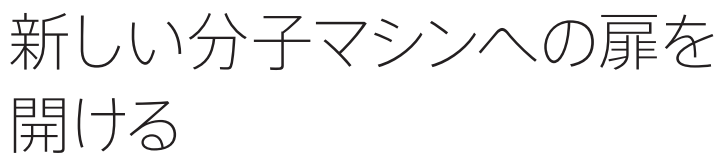

生物モ一ターは多くの細胞内過程を駆動している。すで に、これに似せた合成モーターがいくつも開発されてお り、ナノマシンとして機能している。しかしながら、天 然の分子マシンと人工の分子マシンの間には大きな違い がある。例えば、筋肉の収縮に関与する生物的モーター などは化学系を平衡から遠ざけるように作用するのに 対して、化学者が合成するマシンは平衡に近づけるよう に作用するものばかりだったのである。

英国エジンバラ大学の David Leighの研究室が新し い一歩を踏み出したのは、彼らが分子マシンの製作に取 り組むようになってから 10 年が経過した頃のことだっ た。2003年のミーティングで、Leigh は博士課程の学 生だったEuan Kayに、生体分子モーターの仕組みにつ いて理論物理学者がどのような提案をしているかを調 べて発表するように依頼した。「彼は、理論物理学者が 提案していたさまざまな機構を有機化学者にも理解で きる言葉で説明するという離れ業をやってのけたのだ」 とLeigh は回想する。「彼の発表が終わる頃には、目か らウロコが落ちたような気分になっていた」。自然に分 布している粒子の位置を変えられる分子マシンを合成し ようと彼らが思い立ったのはそのときだった。

彼らの分子マシンのデザインは、物理学者James Clerk Maxwellが140 年前に提案した思考実験をヒン トにしている。Maxwell は、気体が充満した2つの容 器の仕切りに開いた小さなドアを開けたり閉めたりす る小さな魔物を考え出した。魔物は、右の容器から特 に高速の気体分子がやってきた場合にのみ、ドアを開 けてこれを左の容器に通すということをしている。た だそれだけで、左の容器には高速の気体分子が集まっ て温度が徐々に上がっていき、右の容器の温度は下がっ てくる。このように、外部からエネルギーを加えること なく自然に加熱と冷却が起こるなら、それは熱力学の

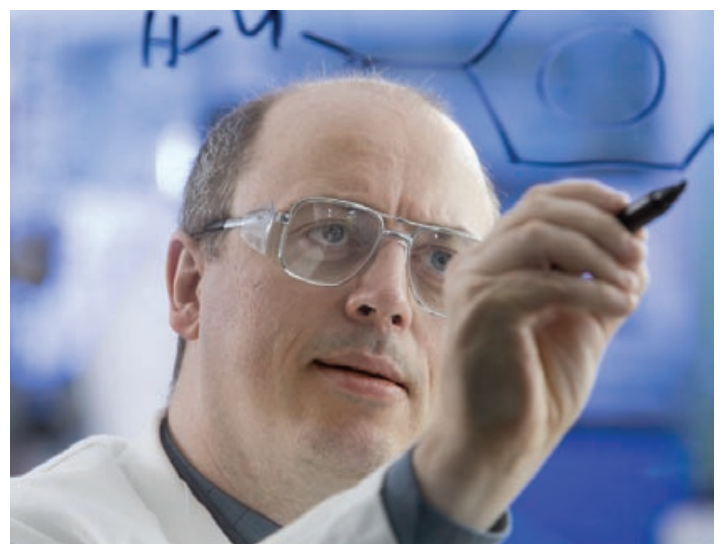

第二法則に反している。熱力学の第二法則にはいろい ろな表現のしかたがあるが、その1つに、「外部から工 ネルギーを加えることなく系の秩序が増すことはない」 というものがあるからである。

Leighのチームは、Maxwellの魔物のような動作に より、粒子の相対的な位置に応じてこれを選別する分 子マシンを設計した。この分子はロタキサンとよばれ、 両端に大きなストッパーがついた直鎖状のパーツに環状 のパーツが引っかかった構造をしている。直鎖状のパー ツの左寄りの位置には「ゲート」があって、環状のパー ツが左右に動き回るのを阻止している。

環がゲートの左側にあるときに光が当たると、環が 受け取った光エネルギーがゲートに伝わり、ゲートが開 く。そこで環が右側に移動すると、再びゲートが閉じる。 逆に、環がゲートの右側にあるときには、ゲートからの 距離が遠すぎるため、受け取った光エネルギ一を伝えて ゲートを開くことができない。その結果、粒子は右側に 蓄積して、系の秩序が増すことになる。なお、この系 には光エネルギーが加えられているので、熱力学の第二 法則には反していない。

同研究室の博士候補のViviana Serreli とポスドクの Chin-Fa Leeは、この作業を遂行できるロタキサンを3 年以上かけて構築した。チームはその間、小さなパーツ をいくつも合成し、テストしては、そのデザインを洗練 させていった。そしてついに、すべてのパーツを組み合 わせた分子マシンが完成したのである。「最初に光を照射 して、平衡状態にあった環の分布が変わっていくのを目 にしたときには、畏敬の念に満たされた」とLeighはいう。

彼は今、生体膜に組み込まれているポンプのような機 能をもつ分子モ一ターを合成しようと計画している。「私 たちは、今日の分子マシンよりもはるかに進んだものを 作り出したいのだ」と彼はいう。 